\title{
13. EVOLUTION OF CENOZOIC CLAY ASSEMBLAGES IN THE BARBADOS RIDGE (DEEP SEA DRILLING PROJECT SITES 541, 542, 543) ${ }^{1}$
}

\author{
C. Latouche and N. Maillet, Institut de Géologie du Bassin d'Aquitaine, Université de Bordeaux I²
}

\begin{abstract}
This chapter deals with the evolution of clay minerals in Cenozoic sediments from DSDP Sites 541, 542, and 543 east of the Lesser Antilles arc on and near the edge of the Barbados Ridge complex. Throughout the Miocene, smectite exceeds all other minerals at all three sites. From the Pliocene onward, however, illite becomes dominant and chlorite well-represented. Quantitative mineral differences among the three sites are significant up until the top of the Pliocene. But in the Pleistocene, the mineralogical composition becomes exactly the same at all sites. Data from the Caribbean region are used to interpret the results obtained. These involve two supply sources: (1) the adjacent islands that supply smectites and kaolinites, and (2) South America, which is the major source of illite and chlorite. The apparent northward migration of illite and chlorite on the Barbados Ridge complex and the changes reported in the quantitative distribution of the four clay minerals are most probably controlled by northerly currents along the northern coast of South America.
\end{abstract}

\section{INTRODUCTION}

The average content of clay minerals in sediments cored at Sites 541 through 543 during Leg $78 \mathrm{~A}$ were calculated for each main geological stage on the basis of clay-fraction analysis results $(<2 \mu \mathrm{m})$. The stage boundaries are those given in Bergen (this volume) - based on nannofossils; Renz (this volume)-based on radiolarians; and, for part of the Eocene, the site reports (this volume)based on foraminifers. The sediments, which range from Tertiary to Quaternary, were recovered on the Barbados Ridge (Sites 541 and 542) and at the oceanic reference site (543) just east of the Barbados Ridge. Methods and mineralogical data are presented in the Appendix. For the evaluation of mean contents, neither transitional zones nor insufficiently well-determined ages were taken into consideration. Experimental error is estimated to be $\pm 10 \%$, in accordance with the analysis of artificial mixtures of clay minerals. After a brief summary of the results obtained, we discuss the evolution of the clay phases from a paleogeographical point of view.

\section{RESULTS}

\section{Site 541}

Two successive Miocene-Pliocene tectonic units (A and B, see Site 541 report and Biju-Duval et al., 1981) and Pleistocene sediments were studied (Table 1, Fig. 1A).

Miocene sediments (Tectonic Units A and B) are characterized by the predominance of smectite; illite, kaolinite, and chlorite are far less abundant but well-represented.

Pliocene sediments (Tectonic Units A and B) are also rich in smectite but contain more illite than the Miocene deposits. Kaolinite and chlorite amounts remain practi-

\footnotetext{
1 Biju-Duval, B., Moore, J. C., et al., Init. Repts. DSDP, 78A: Washington (U.S. Govt. Printing Office).

2 Address: Institut de Géologie du Bassin d'Aquitaine, Université de Bordeaux I, 351 Cours de la Libération 33405 Talence, France.
}

Table 1 . Mean clay mineral contents $(\%)$ in each suratigraphic unit, Site 541 .

\begin{tabular}{|c|c|c|c|c|c|}
\hline Stratigraphic unit & $\begin{array}{c}\text { Levels } \\
\text { (core-section, } \\
\text { interval in cm) }\end{array}$ & Smectite & Illite & Kaolinite & Chlorite \\
\hline Pleistocene & $\begin{array}{l}2-6,18-20 \text { to } \\
11-2,11-13 \\
\text { (17 samples) }\end{array}$ & 32 & 33 & 20 & 15 \\
\hline $\begin{array}{l}\text { Pliocene } \\
\text { (Tectonic Unit A) }\end{array}$ & $\begin{array}{l}12-4,89-91 \text { to } \\
20-2,70-72 \\
\text { (15 samples) }\end{array}$ & 52 & 23 & 16 & 9 \\
\hline $\begin{array}{l}\text { Miocene } \\
\text { (Tectonic Unit A) }\end{array}$ & $\begin{array}{c}22-6,126-127 \text { to } \\
30-6,8-10 \\
\text { (10 samples) }\end{array}$ & 56 & 21 & 14 & 9 \\
\hline $\begin{array}{l}\text { Pliocene } \\
\text { (Tectonic Unit B) }\end{array}$ & $\begin{array}{l}30-7,8-10 \text { to } \\
33-6,94-96 \\
\text { (4 samples) }\end{array}$ & 41 & 30 & 18 & 11 \\
\hline $\begin{array}{l}\text { Miocene } \\
\text { (Tectonic Unit B) }\end{array}$ & $\begin{array}{c}37-6,94-96 \text { to } \\
50-3,48-50 \\
\text { (11 samples) }\end{array}$ & 59 & 17 & 16 & 8 \\
\hline
\end{tabular}

cally the same as those observed in the Miocene sediments.

Pleistocene sediments, although rich in smectite, display richer illite proportions than in the Miocene. Kaolinite and chlorite amounts are higher than those observed in the Pliocene sediments.

\section{Site $\mathbf{5 4 2}$}

Only upper Miocene and Pliocene sediments were studied; Pleistocene sediments were excluded because they were not clearly and stratigraphically distinguished within the Quaternary deposits (Table 2, Fig. 1B).

Here the Miocene sediments are also characterized by the predominance of smectite. Illite, kaolinite, and chlorite are less abundant than in the Miocene of Site 541.

In the Pliocene, smectite decreases considerably, although it is still dominant, whereas illite, kaolinite, and chlorite are more abundant than in the Miocene.

\section{Site 543}

The sediments studied belong to the Eocene, Oligocene, Miocene, Pliocene, and Pleistocene (Table 3, Fig. 1C). 

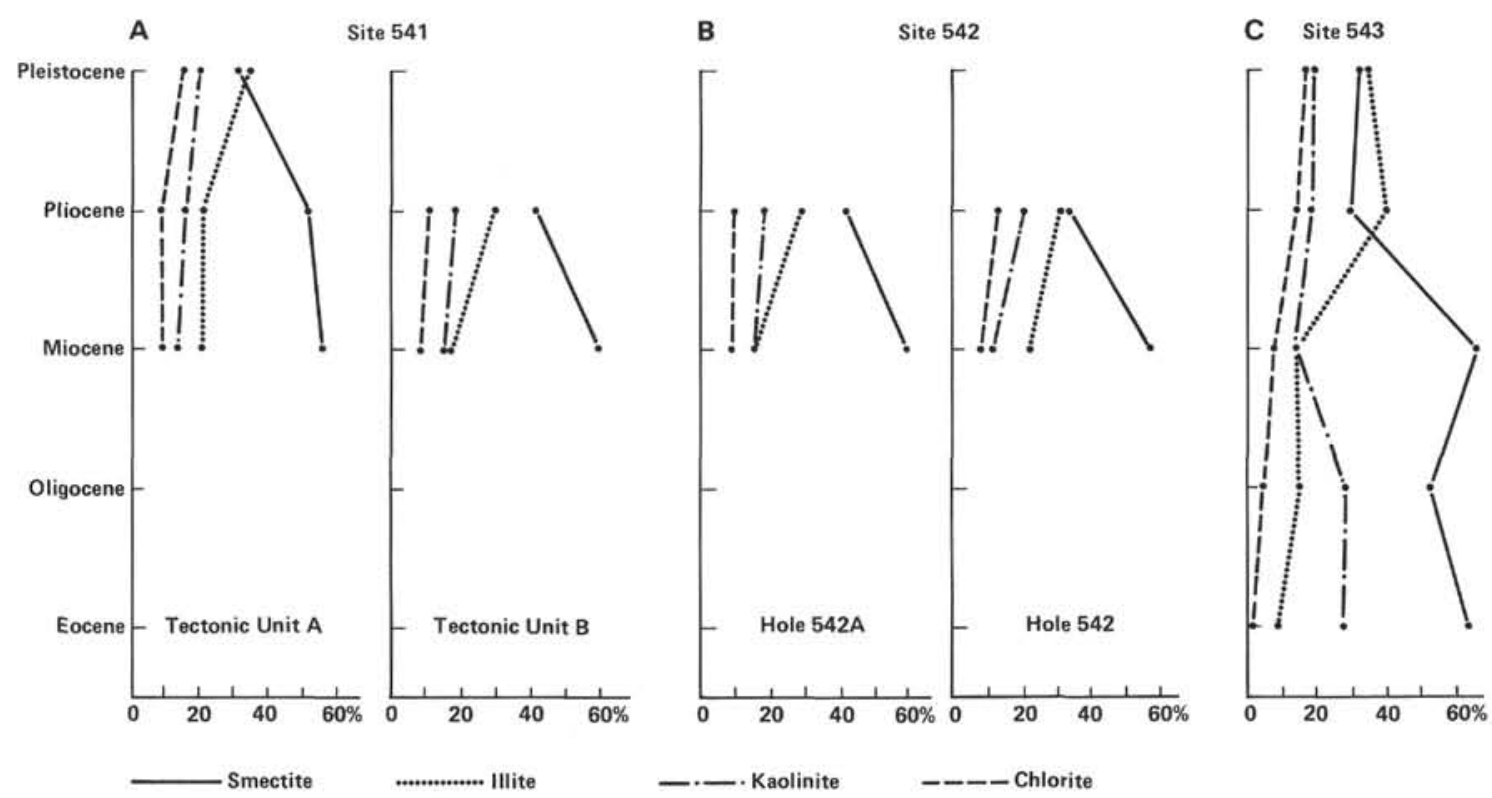

Figure 1. A-C. Clay-mineral assemblage variations during the Tertiary and Quaternary, averaged by epoch, from data in Appendix Tables 1-3.

Table 2. Mean clay mineral contents $(\%)$ in each straigraphic unit, Site 542 .

\begin{tabular}{|c|c|c|c|c|c|}
\hline $\begin{array}{c}\text { Stratigraphic } \\
\text { unit }\end{array}$ & $\begin{array}{c}\text { Levels } \\
\text { (core-section, } \\
\text { interval in cm) }\end{array}$ & Smectite & Illite & Kaolinite & Chlorite \\
\hline \multicolumn{6}{|l|}{ Hole $542 \mathrm{~A}$} \\
\hline Pliocene & $\begin{array}{c}\text { H1-5, 87-89 } \\
\text { H2-5, 60-62 } \\
1-4,61-63 \\
\text { (3 samples) }\end{array}$ & 43 & 29 & 18 & 10 \\
\hline Miocene & $\begin{array}{c}3-1,106-108 \text { to } \\
8-4,40-42 \\
\text { (7 samples) }\end{array}$ & 59 & 16 & 16 & 9 \\
\hline \multicolumn{6}{|l|}{ Hole 542} \\
\hline Pliocene & $\begin{array}{c}\mathrm{H} 2-4,60-62 \\
\mathrm{H} 3-1,35-37 \\
2-4 \\
\text { (3 samples) }\end{array}$ & 34 & 31 & 21 & 14 \\
\hline Miocene & $\begin{array}{c}4-1,36-37 \text { to } \\
4-2,112-119 \\
\text { (3 samples) }\end{array}$ & 57 & 22 & 12 & 9 \\
\hline
\end{tabular}

Eocene clays are marked by their high smectite contents. Kaolinites are quite abundant; some illite and chlorite traces were observed.

Smectite and kaolinite remain dominant in Oligocene sediments; illite in particular as well as chlorite increase considerably.

Miocene clay minerals are dominated by smectite. Kaolinite diminishes markedly, whereas illite remains the same as observed in the Oligocene at this site. Chlorite shows a moderate increase.

The Pliocene sediments are dominated by illite and smectite. Kaolinite and chlorite are more abundant than in the subjacent episode.

In the Pleistocene, illite, smectite, kaolinite, and chlorite proportions remain practically the same as those reported for the Pliocene.
Table 3. Mean clay contents (\%) in each stratigraphic unit, Site 543.

\begin{tabular}{|c|c|c|c|c|c|}
\hline $\begin{array}{c}\text { Stratigraphic } \\
\text { unit }\end{array}$ & $\begin{array}{c}\text { Levels } \\
\text { (core-section, } \\
\text { cm interval) }\end{array}$ & Smectite & Illite & Kaolinite & Chlorite \\
\hline Pleistocene & $\begin{array}{c}1-2,50-52 \text { to } \\
3-5,14-16 \\
\text { (3 samples) }\end{array}$ & 31 & 34 & 19 & 16 \\
\hline Pliocene & $\begin{array}{c}4-1,100-102 \text { to } \\
7-3,22-24 \\
\text { (4 samples) }\end{array}$ & 29 & 39 & 18 & 14 \\
\hline Miocene & $\begin{array}{c}10-4,120-122 \text { to } \\
23-2,137-139 \\
\text { (15 samples) }\end{array}$ & 65 & 14 & 14 & 7 \\
\hline Oligocene & $\begin{array}{c}24-3,115-116 \text { to } \\
26-4,110-112 \\
\text { (5 samples) }\end{array}$ & 52 & 16 & 28 & 4 \\
\hline Eocene & $\begin{array}{c}27-4,83-85 \text { to } \\
30-4,93-94 \\
\text { (5 samples) }\end{array}$ & 64 & 8 & 27 & 1 \\
\hline
\end{tabular}

In summary, on the basis of these data, the mineralogical evolution of the region varied greatly in time. Sediments dominated by smectite and kaolinite prevailed during the Eocene and Oligocene; during the Miocene, kaolinite disappeared and only smectite predominated. This predominance gave way to that of illite during the Pliocene and Pleistocene. This clay-mineral transition is abrupt at the oceanic reference site (543), and more gradational at the other sites (541 and 542).

\section{DISCUSSION}

\section{Interpretation of Results}

Interpretation of results is based upon previous studies by different authors, which concern, first, the general definition of clays within sedimentary environments and second, the distribution of these minerals in presentday soils and sediments of the Caribbean region and its 
surroundings. The conclusions of all these studies guided us to the interpretation suggested herein.

In general, clayey marine sediments (see Biscaye, 1965; Griffin et al., 1968; Chamley, 1981) are considered to be mainly the result of erosion from neighboring continental soils. They can, therefore, indicate the origin and conditions under which those soils evolved. From this point of view, kaolinites are the result of a hot, very damp, leaching climate. Smectite can develop in Vertisols in hot climates of contrasting seasons (humid-dry) in badly drained zones (Paquet, 1970). The presence of parent basic volcanic rocks is often considered to be a factor favoring development of smectite. Illite and chlorite can form in temperate climates and/or by simple mechanical weathering of acidic rocks. Clay minerals may also be the result of authigenesis within the sedimentary environment itself. They can, therefore, act as environmental indicators. For instance, Bonatti (1967) and Lomova (1975) showed that volcanic environments favor the development of smectite and palygorskite. Diagenesis and metamorphism may also account for the relatively important changes of clay minerals after settling, that is "fermeture" (Millot, 1964), of the rather degraded structures of certain minerals (early diagenesis) and transformation into illite and chlorite (metamorphism).

Since the work of Delany et al. (1967) and of Griffin and Goldberg (1969), various modern clay sediments recovered in the Caribbean region have been the object of many studies. Several of these studies contributed to our interpretation. First, soil studies in Martinique (Julius and Pons, 1972) showed that smectite and kaolinite are the sole clay components. Second, studies carried out on present-day marine deposits neighboring the Lesser Antilles (Pautrizel and Pons, 1981), Columbia (Klingebiel and Vernette, 1977), Guiana (Jantet, 1982), and the outlets of the Orinoco and Amazon rivers (Damuth and Fairbridge, 1970; Embley and Langseth, 1977; Gibbs, 1977; Eisma et al., 1978; Bouysse et al., 1980) suggested that illite and chlorite originate from the northern part of South America. Once in the sea, they migrate toward the northwest (Fig. 2) under the effect of currents along the continental shelf (Guiana currents) and deep-water currents (Antarctic Bottom Waters-AABW). They can mix with locally derived clay minerals (smectite, kaolinite) in the vicinity of the Lesser Antilles.

\section{Evolution of Clay Mineral Assemblages in the Cenozoic at Site 543}

The stratigraphic series at this site is the most complete. Hence this site served as a means of tracing the evolution of clay minerals during the Tertiary and Quaternary (Fig. 1C).

Eocene clay minerals are mainly represented by smectite and kaolinite. This assemblage is, in general, that of soils in equatorial regions (Millot, 1964; Tardy, 1969). It particularly occurs in soils overlying present-day volcanic material of the Lesser Antilles (Julius and Pons, 1972). The prevailing mineral in well-drained areas of the islands is kaolinite, whereas in the lowlands it is smectite.

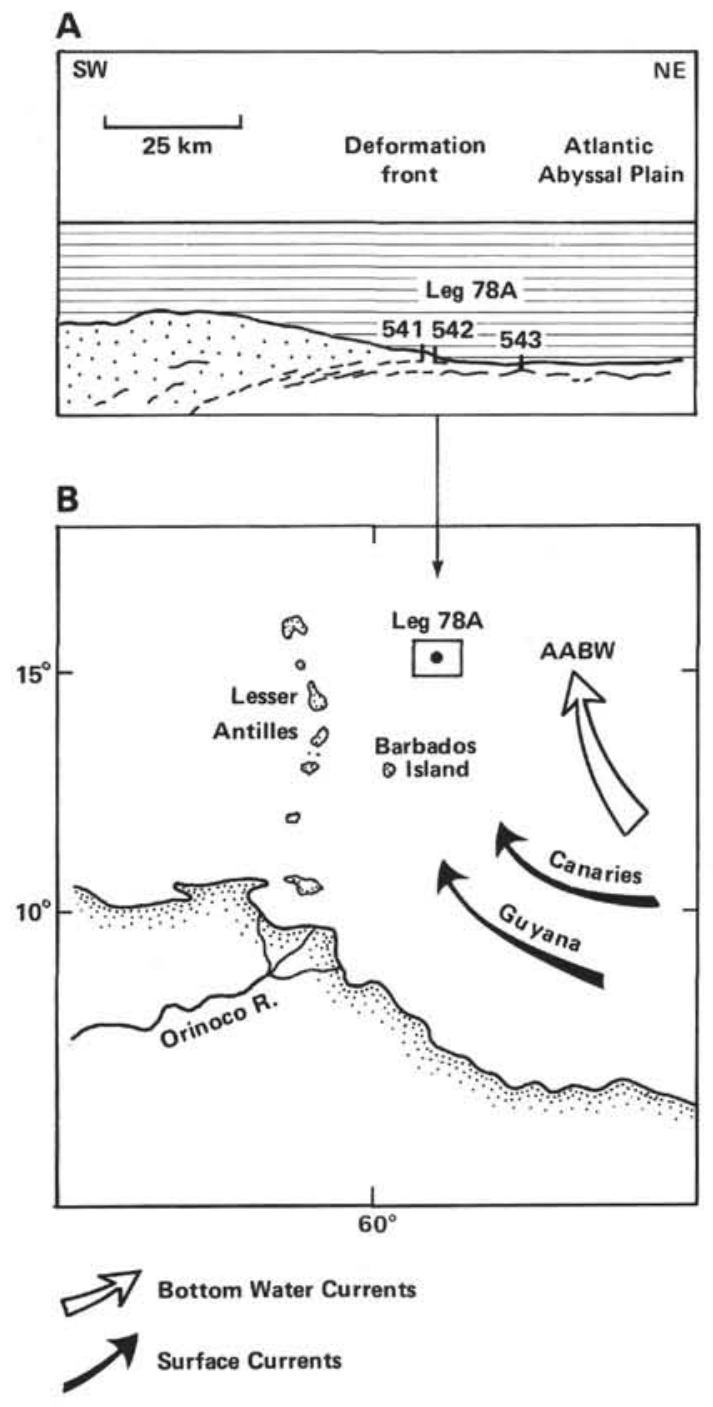

Figure 2. Location of the Leg 78A drilling area (Sites 541, 542, and 543). A. Schematic profile of the Barbados Ridge complex (after Biju-Duval et al., 1981). Sites 541 and 542 penetrated chiefly Miocene and younger sediments above the upper reflector, shown schematically. Site 543 reached Late Cretaceous basaltic basement, the lower reflector shown schematically. B. Leg 78A drilling area in relation to the Lesser Antilles arc, northern South America, and present-day surface and bottom currents (from Damuth and Fairbridge, 1970; Embley and Langseth, 1977). (AABW = Antarctic Bottom Water.)

Some zeolite traces (clinoptilolite) associated with the clay fraction also occur at Site 543. This zeolite as well as the frequent occurrence (see Natland, this volume; Biju-Duval et al., 1981) of volcanic ash suggest submarine diagenesis of smectite from basic eruptive precursors; hence the significantly higher smectite contents that were observed in lower Eocene sediments, which have rare altered volcanic ashes (Natland, this volume). Nevertheless, close examination of the distribution of smectite (level by level) in these Eocene sediments showed no correlation between smectite contents and ash layers. Although the possibility of a direct influence by volcanic ash on smectite genesis cannot be excluded, we be- 
lieve that the main sources of this material-and the associated kaolinite-are soils overlying basic eruptive rocks that develop under an equatorial climate.

The Oligocene is represented by the same smectitekaolinite assemblage. In this unit, very few ash levels have been recognized (Natland, this volume); thus volcanism cannot have greatly contributed to the in situ genesis of clay minerals. Erosion of soils appears, here again, to be the main source of these minerals. This shows that clay-mineral supply occurred under the same general equatorial climatic conditions as those during the Eocene. But at the same time, the very presence of primary minerals such as illite or chlorite indicates that new inputs existed and resulted from the erosion of unaltered or only slightly altered acidic rocks (e.g., metamorphic rocks or granite). These primary minerals cannot be truly compatible features of either the climatic or geologic contexts that are marked by the abundance of smectite. They could be indicative of continental tectonic rejuvenation and/or of new inputs derived from nonequatorial regions.

Miocene clay minerals are mostly represented by smectites. The moderate increase of the smectite-kaolinite ratio could suggest less humidity (i.e., rainfall) and larger areas of poorly drained soils, possibly corresponding to the general Miocene submergence of the arc (Tomblin, 1975). This increase can also be correlated with an early middle Miocene increase of explosive volcanic activity (Natland, this volume). Nevertheless, no volcanic material other than smectite is recognized in the upper Miocene. In addition to illite (primary mineral) there is a distinct appearance of chlorite, which could mean that nonequatorial inputs became more abundant.

Pliocene and Pleistocene clay assemblages are fundamentally different from those of the older sediments. Consequently, the Miocene/Pliocene boundary appears as a major mineralogical break. Illite becomes dominant; the smectite percentage remains important but diminishes considerably. The proportions of kaolinite and chlorite are the same and well-represented. From the Pliocene onward the clay compositions become very similar to those observed in the present-day local environments. Thus the modern model outlined earlier can serve as a guide to the understanding of mineralogical changes at the Miocene/Pliocene boundary. Likewise, deposits at Site 543 appear from the Pliocene onward to inherit an important part of clay phases (illite and chlorite) from a nonequatorial source that began to take effect discreetly during the Oligocene. As is the case today (Pautrizel and Pons, 1981), illite and chlorite might have originated in northern part of South America and been transported by Central Atlantic surface currents; these might have deviated during the Cenozoic to the northwest and migrated along the northern part of South America (Berggren and Hollister, 1974). We assumed that this deviation accelerated at the beginning of the Pliocene with the closing of the Panama isthmus (Heath and van Andel, 1973). Fine-grained materials, issued from mountains and today carried to the sea by the Orinoco and Amazon rivers could have drifted toward the north and contributed (after mixing with local terrigenous materi- als, mainly smectites) to the sedimentation of the Barbados Ridge. These materials, formed in high altitudes under temperature to cold climatic conditions, might (despite their equatorial latitude) have been richer in primary clay minerals. If so, the present-day regional model of sedimentation can be applied to the Pliocene. Even as early as the Oligocene, traces of illite and chlorite suggest a modest South American supply.

\section{COMPARISON OF SITE 543 WITH SITES 541 AND $\mathbf{5 4 2}$}

Upper Cenozoic sediments at Sites 541 and 542 show the same succession of clay minerals as sediment at Site 543.

Smectite is again dominant in the Miocene; primary minerals, especially illite, are abundant in the Pliocene but predominate in the Pleistocene (Site 541). In the Miocene, smectite is slightly more dominant at Site 543 than at Sites 542 and 541 , where the primary minerals are better represented. Conversely, in the Pliocene (Fig. 3), illite is predominant at Site 543 and less abundant at the other sites. In the Pleistocene, clay phases are identical at both Sites 541 and 543. Illite predominates over smectite; chlorite is fairly well-represented.

Arguments used to interpret the sedimentary situation at Site 543 may also be used to explain the data as a whole. They involve two supply sources: one local-the

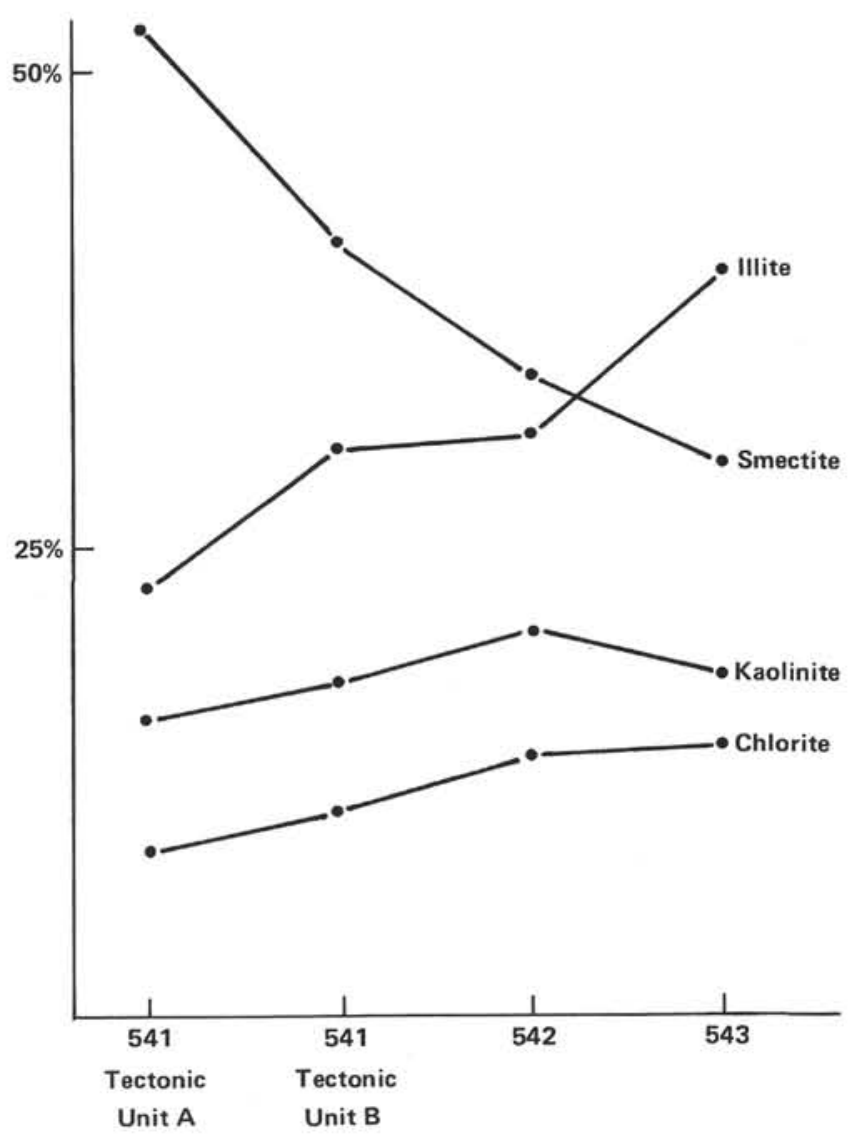

Figure 3. Comparison of clay assemblage differences at Sites 541, 542, and 543 during the Pliocene. 
Lesser Antilles-rich in kaolinite and smectite; and the other distant-South America-rich in illite and chlorite.

Up until the end of the Miocene, Site 543 was located more to the east than today and consequently it was less able to receive materials derived from South America. At this time, Sites 541 and 542, however, were in a region supplied both by the Lesser Antilles arc and, to a lesser extent, South America.

During the Pliocene, convergence of the North American and Caribbean plates brought Site 543 closer to the arc, and in the path of currents transporting South American material. Also, the simultaneous closing of the Panama isthmus resulted in the migration of these currents more to the east, hence more directly toward Site 543.

\section{ACKNOWLEDGMENTS}

We wish to thank J. P. Peypouquet and R. Blanchet for reading the manuscript, as well as J. Natland for his useful advice on its improvement. We are also grateful to J. J. Griffin and K. Balshaw-Biddle for their critical revision of the text. We thank J. Esquevin, C. Sourisse and P. Valéry for authorizing us to use certain analytical data obtained at Société National Elf Aquitaine (Production) Pau, France.

\section{REFERENCES}

Berggren, W. A., and Hollister, C. D., 1974. Paleogeography, paleobiogeography, and the history of circulation in the Atlantic Ocean. In Hay, W. (Ed.), Studies in Paleoceanography, Soc. Econ. Palontol. Mineral., 20:126-186.

Biju-Duval, B., Moore, J. C., Blackinton, G., Bergen, J. A., Claypool, G. E., Cowan, D. S., Guerra, R. T., Hemleben, C. H., Marlow, M. S., Natland, J. H., Pudsey, C. J., Renz, G. W., Tardy, M., Willis, M. E., Wilson, G., and Wright, A. A., 1981. Premiers rèsultats des forages IPOD implantés lors de la croisière 78A du Glomar Challenger au nord-est de la ride de la Barbade (arc des Petites Antilles): tectonique frontale d'un prisme d'accrétion. C. R. Acad. Sci. Paris, 293:621-628.

Biscaye, P. E., 1965. Mineralogy and sedimentation of recent deep-sea clay in the Atlantic Ocean and adjacent seas and oceans. Geol. Soc. Am. Bull., 76:803-832.

Bonatti, E., 1967. Mechanisms of deep-sea volcanism in the South Pacific. Res. Geochem., 2:453-491.

Bouysse, P., Vairon, P., and Zeegers, H., 1980. Géochimie dés sédiments superficiels du plateau continental de la Guyanne française. Bull. Inst. Geol. Bassin Aquitaine, 28:92-114.

Chamley, H., 1981. Long-term trends in clay deposition in the ocean. Oceanol. Acta, 3P:105-110.

Damuth, J. E., and Fairbridge, R. W., 1970. Equatorial Atlantic DeepSea ankosic sands and ice-age aridity in tropical South America. Geol. Soc. Am. Bull., 81:189-206.

Delany, A. C., Delany, A. C., Parkin, D. W., Griffin, J. J., Goldberg, E. D., and Reimann, B. E. F., 1967. Airborne dust collected at Barbados. Geochim. Cosmochim. Acta, 31:885-909.

Eisma, D., Van der Gaast, S. J., Martin, J. M., and Thomas, A. J., 1978. The Orinoco Delta, turbidity, mineralogy and elementary composition. Neth. J. Sea Res., 12(2):224-251.

Embley, R. W., and Langseth, M. G., 1977. Sedimentation processes on the continental rise of northeastern South America. Mar. Geol., 25:297-297.

Gibbs, R., 1977. Clay mineral segregation in the marine environment. J. Sedimentol. Lett., 47:237-243.

Griffin, J. J., and Goldberg, E. D., 1969. Recent sediments of Caribbean Sea. Soc. Econ. Paleontol. Mineral., SP11, Am. Assoc. Pet. Geol., pp. 258-268.

Griffin, J. J., Windom, H., and Goldberg, E. D., 1968. The distribution of clay minerals in the world ocean. Deep-Sea Res., 15(4): 433-459.
Heath, G. R., and van Andel, T. H., 1973. Tectonics and sedimentation in the Panama Basin: geologic results of Leg 16, Deep Sea Drilling Project. In van Andel, T. H., Heath, G. R., et al., Init. Repts. DSDP, 16: Washington (U.S. Govt. Printing Office), 899-913.

Jantel, D., 1982. Etude de la couverture sédimentair superficielle de la marge continentale guyanaise. [Ph.D. dissert.]. Université de Bordeaux I, $\mathrm{n}^{\circ} 1753$.

Julius, C., and Pons, J. C., 1972. Contribution à l'étude d'une mangrove de la région de Vauclin (Marintique). Bull. Inst. Geol. Bassin Aquitaine, 12:181-186.

Klingebiel, A., and Vernette, G., 1977. Résultats préliminaires de la mission océanographique franco-colombienne en Juin 1975. Bull. Inst. Geol. Bassin Aquitaine, 22:157-164.

Lomova, O. S., 1975. Abyssal palygorskite clays of the eastern Atlantic and their genetic relation to Atlantic volcanism (from data of Legs 2 and 14 of the Glomar Challenger). Litol. I. Polzn. Iskop., 4:10-27.

Millot, R., 1964. Géologie des Argiles: Paris (Ed. Masson).

Paquet, H., 1970. Evolution géochimique des minéraux argileux dans les alterations et les sols des climats méditerannéens tropicaux à saisons contrastées. Mem. Serv. Carte Geol. Alsace Lorraine, 30: 1-210.

Pautrizel, F., and Pons, J. C., 1981. Modalités de la sédimentation au Quaternaire récent dans la mer des Petites Antilles (Fosse de Grenade, ride des Oiseaux, bassin du Vénézuela). Bull. Inst. Geol. Bassin Aquitaine, 30:239-262.

Tardy, Y., 1969. Géochimie des altérations. Etude des arènes et des eaux de quelques massifs cristallins d'Europe et d'Afrique. Mem. Serv. Carte Geol. Alsace Lorraine, 31:1-199.

Tomblin, J. F., 1975. The Lesser Antilles and Aves Ridge. In Nairn, A. E. M., and Stehli, F. V. (Eds.), The Ocean Basins and Margins (Vol. 3): New York (Plenum), 467-500.

Date of Initial Receipt: May 27, 1982

Date of Acceptance: October 24, 1983

\section{APPENDIX}

\section{METHODS AND MINERALOGICAL DATA}

\section{Analytical Procedures}

At the Société Nationale Elf Aquitaine (Production) [SNEA (P)], routine mineralogical $\mathrm{X}$-ray diffraction analyses were performed on the bulk samples and the $<5-\mu \mathrm{m}$ fraction. At the Institut de Géologie du Bassin d'Aquitaine (IGBA), the mineralogical analyses of the finegrained fraction $<2 \mu \mathrm{m}$ were completed.

Quartz, calcite, and dolomite were analyzed by X-ray diffraction as percentages of the total sediment. The diffractometer used was a Philips 1130, and operating conditions were as follows: $\mathrm{CuK} \alpha$ radiation at $40 \mathrm{kv}, 30 \mathrm{~mA}$; monochromator; Compton diffusion measurement were made to obtain matrix effect correction by computing programme.

\section{Clay Fraction $<\mathbf{5} \mu \mathrm{m}$}

Separating methods were the same as those used for clay fraction $<2 \mu \mathrm{m}$, but $5-\mu \mathrm{m}$-grained fractions were extracted and the suspensions deposited on slides. The diffractometer used was a Philips 1130, and operating conditions were as follows: very fine focus, nickel-filtered $\mathrm{CuK} \alpha$ radiation at $40 \mathrm{kV}, 20 \mathrm{~mA}$.

\section{Clay Fraction $<2 \mu \mathrm{m}$}

Total sediments were dispersed in pure water using mechanical agitation. Samples with high contents of carbonates were first treated with 10 normal $\mathrm{HCl}$. After several (2 or 3 ) washings in pure water, the $<2-\mu \mathrm{m}$ subfractions were separated by gravity settling. The $<2-\mu \mathrm{m}$ portion was centrifuged, and the thick paste obtained was spread across two slides with a standard laboratory spatula. The first slide was scanned untreated and then treated at $550^{\circ} \mathrm{C}$ for $1 \mathrm{hr}$. before secondary analysis. Minerals were identified on the basis of their typical reactions to classical treatment (Brown, 1961; Thorez, 1975). The different minerals were estimated semiquantitatively from diagrams of the glycolated slides. Their relative abundance in the clay fraction was evaluated on 


\section{LATOUCHE, N. MAILLET}

the basis of the height of their basal characteristic reflections. Experimental error was estimated to $\pm 10 \%$ (relative value), in accordance with the analysis of artificial mixtures of pure clay minerals.

The diffractometer used was a Philips 1130. Operating conditions were as follows: $\mathrm{CuK} \alpha$ radiation, $40 \mathrm{kV}, 20 \mathrm{~mA}$.

Data are listed in Tables 1 (Site 541), 2 (Site 542), and 3 (Site 543). They are plotted versus depth in Figures 1 (Site 541), 2 (Site 542), and 3 (Site 543).

\section{REFERENCES}

Brown, G., 1961. The X-ray Identification and Crystal Structures of Clay Minerals: London (Mineralogical Society).

Thorez, J., 1975. Phyllosilocates and Clay Minerals. A Laboratory Handbook for Their X-Ray Diffraction Analysis: Dison, Belgique (G. Lelotte Edit.).

Table 1. Leg 78A Hole 541 mineralogical data, obtained by X-ray diffraction analysis.

\begin{tabular}{|c|c|c|c|c|c|c|c|c|c|c|c|c|c|c|c|}
\hline \multirow[b]{2}{*}{$\begin{array}{c}\text { Sample } \\
\text { (core-section, } \\
\text { cm interval) }\end{array}$} & \multicolumn{3}{|c|}{ Total rock $(\%)$} & \multicolumn{6}{|c|}{ Composite $<5-\mu \mathrm{m}$ fraction } & \multicolumn{4}{|c|}{ Composite $<2-\mu \mathrm{m}$ fraction } & \multirow[b]{2}{*}{$\begin{array}{l}\text { Smectite } \\
\text { crystal- } \\
\text { linity }\end{array}$} & \multirow[b]{2}{*}{$\frac{\text { Quartz }}{\text { feldspar }^{\text {c }}}$} \\
\hline & $\begin{array}{c}\text { Dolo- } \\
\text { mite }\end{array}$ & Calcite & $\begin{array}{c}\text { Quartz } \\
(\%)\end{array}$ & $\begin{array}{c}\text { Chlorite } \\
(\%)\end{array}$ & $\begin{array}{l}\text { Kao- } \\
\text { linite } \\
(\%)\end{array}$ & $\begin{array}{l}\text { Illite } \\
(\%)\end{array}$ & $\begin{array}{l}\text { I-S } \\
(\%)\end{array}$ & $\begin{array}{c}\text { Smectite } \\
(\%)\end{array}$ & $\begin{array}{c}\text { Chlorite } \\
(\%)\end{array}$ & $\begin{array}{l}\text { Kao- } \\
\text { linite } \\
(\%)\end{array}$ & $\begin{array}{l}\text { Illite } \\
(\%)\end{array}$ & $\begin{array}{c}\text { Smectite } \\
(\%)\end{array}$ & $\begin{array}{l}\text { Atta- } \\
\text { pulgite } \\
(\%)\end{array}$ & & \\
\hline $2-1,42 ?$ & & 14 & 8 & 8 & 12 & 10 & 20 & so & & & & & & & \\
\hline $2-5,110-112$ & & & 12 & & 25 & 7 & 20 & 48 & & & & & & & \\
\hline $2-6,18-20$ & & & & & & & & & 18 & 18 & 32 & 32 & & & 1.58 \\
\hline $3-1,59-61$ & & & & & & & & & 16 & 22 & 36 & 26 & & 0.11 & 4.00 \\
\hline $3-2,94-96$ & & 12 & 6 & & 21 & 6 & 20 & 53 & & & & & & & \\
\hline $3-3,59-61$ & & & & & & & & & 17 & 22 & 36 & 25 & & 0.33 & 4.80 \\
\hline $3-4,53-55$ & & 1 & 11 & & 10 & 5 & 10 & 75 & & & & & & & \\
\hline $3-4,59-61$ & & & & & & & & & 17 & 23 & 35 & 25 & & 0.27 & 5.70 \\
\hline $4-1,103-105$ & & 21 & 8 & & 21 & 6 & 16 & 57 & & & & & & & \\
\hline $4-2,33-35$ & & & & & & & & & 19 & 21 & 32 & 28 & & 0.27 & 5.00 \\
\hline $4-4,33-35$ & & & & & & & & & 13 & 22 & 36 & 29 & & 0.22 & 5.55 \\
\hline $4-6,33-35$ & & & & & & & & & 16 & 20 & 35 & 29 & & 0.32 & 5.20 \\
\hline $4-7,22-24$ & & 10 & 9 & & 20 & 10 & 14 & 56 & & & & & & & \\
\hline $4-7,33-35$ & & & & & & & & & 16 & 18 & 33 & 33 & & 0.26 & 4.00 \\
\hline $5-1,88-90$ & & & 9 & & 19 & 8 & 18 & 65 & & & & & & & \\
\hline $5-1,94-96$ & & & & & & & & & 12 & 20 & 34 & 34 & & 0.28 & 1.80 \\
\hline $5-2,103-105$ & & & 10 & & 28 & 4 & 18 & 50 & & & & & & & \\
\hline $5-3,62-64$ & & & & & & & & & 13 & 21 & 34 & 32 & & 0.27 & 2.18 \\
\hline $6-1,13-14$ & & 6 & 7 & 5 & 10 & 5 & 14 & 66 & & & & & & & \\
\hline $6-1,43-45$ & & & & & & & & & 15 & 17 & 30 & 38 & & 0.70 & 2.83 \\
\hline $6-6,90-92$ & & 2 & 6 & & 17 & 5 & 10 & 68 & & & & & & & \\
\hline $7-2,41-43$ & & & & & & & & & 18 & 20 & 31 & 31 & & 0.31 & 4.75 \\
\hline $7-2,46-48$ & & & & & & & & & 16 & 18 & 29 & 37 & & 0.27 & 4.75 \\
\hline $7-2,99-101$ & & 5 & 10 & & & & 5 & 95 & & & & & & & \\
\hline $7-4,53-55$ & & 1 & 10 & & 5 & 3 & 6 & 86 & & & & & & & \\
\hline $8-2,73-75$ & & 3 & 11 & & 15 & 5 & 8 & 72 & & & & & & & \\
\hline $8-4,71-73$ & & 28 & 7 & & 10 & 5 & 10 & 75 & & & & & & & \\
\hline $8-4,80-82$ & & & & & & & & & 11 & 19 & 34 & 36 & Traces & 0.28 & 3.20 \\
\hline $9-2,71-73$ & & 20 & 7 & & 8 & 2 & 8 & 82 & & & & & & & \\
\hline $9-3,71-73$ & & & & & & & & & 14 & 18 & 28 & 40 & & 0.41 & 5.50 \\
\hline $9-4,71-73$ & & 22 & 9 & & 8 & 4 & 6 & 82 & & & & & & & \\
\hline $10-2,72-74$ & & 32 & 6 & & 15 & 5 & 10 & 70 & & & & & & & \\
\hline $10-5,72-74$ & & 24 & 6 & & 15 & 7 & 8 & 70 & & & & & & & \\
\hline $10-5,107-109$ & & & & & & & & & 16 & 19 & 32 & 33 & & 0.32 & 2.55 \\
\hline $11-1,80-82$ & & 15 & 8 & & 13 & 5 & 4 & 78 & & & & & & & \\
\hline $11-2,11-13$ & & & & & & & & & 11 & 19 & 29 & 41 & & 0.40 & 3.60 \\
\hline $11-3,80-82$ & & & & & 10 & 5 & 12 & 73 & & & & & & & \\
\hline $12-1,78-80$ & & 21 & 8 & & 34 & 6 & 12 & 48 & & & & & & & \\
\hline $12-3,78-80$ & & 19 & 8 & & 25 & 5 & 12 & 58 & & & & & & & \\
\hline $12-4,89-91$ & & & & & & & & & 8 & 20 & 20 & 52 & & 0.30 & 5.00 \\
\hline $12-6,78-80$ & & 35 & 5 & 5 & 25 & 14 & 18 & 38 & & & & & & & \\
\hline $13-3,31-33$ & & 25 & 6 & & 34 & 12 & 17 & 37 & & & & & & & \\
\hline $13-5,8-10$ & & & & & & & & & 12 & 22 & 24 & 42 & & 0.40 & 6.00 \\
\hline $13-5,11-13$ & & & & & & & & & 14 & 23 & 23 & 40 & & 0.47 & 6.00 \\
\hline $13-6,31-33$ & & 26 & 7 & 8 & 19 & 17 & 18 & 38 & & & & & & & \\
\hline $14-2,26-28$ & & 28 & 7 & 8 & 16 & 12 & 18 & 46 & & & & & & & \\
\hline $14-2,51-53$ & & & & & & & & & 7 & 15 & 25 & 50 & & 0.50 & 2.44 \\
\hline $14-4,26-28$ & & 32 & 6 & 5 & 19 & 14 & 22 & 40 & & & & & & & \\
\hline $14-7,26-28$ & & 28 & 7 & 10 & 14 & 16 & 18 & 42 & & & & & & & \\
\hline $14-7,51-53$ & & & & & & & & & 10 & 16 & 26 & 48 & & 0.40 & 5.00 \\
\hline $15-2,21-23$ & & 35 & 7 & & 23 & 13 & 20 & 44 & & & & & & & \\
\hline $15-3,21-23$ & & 23 & 7 & & 24 & 14 & 18 & 44 & & & & & & & \\
\hline $15-3,56-58$ & & & & & & & & & 9 & 15 & 23 & 53 & & 0.47 & 5.66 \\
\hline $15-6,21-23$ & & 28 & 5 & & 24 & 15 & 18 & 43 & & & & & & & \\
\hline $16-1,14-16$ & & & & & 24 & 12 & 17 & 47 & & & & & & & \\
\hline $16-1,60-62$ & & & & & & & & & 10 & 14 & 24 & 52 & & 0.47 & 2.16 \\
\hline $16-3,14-16$ & & 26 & 7 & 8 & 19 & 13 & 20 & 40 & & & & & & & \\
\hline $16-3,42-44$ & & & & & & & & & 11 & 18 & 23 & 48 & & 0.56 & 6.00 \\
\hline $16-5,14-16$ & & 26 & 6 & & 20 & 14 & 20 & 46 & & & & & & & \\
\hline $16-6,60-62$ & & & & & & & & & 9 & 12 & 18 & 61 & & 0.50 & 3.00 \\
\hline $17-2,38-40$ & & 27 & 8 & & 26 & 22 & 18 & 34 & & & & & & & \\
\hline $17-3,63-65$ & & & & & & & & & 10 & 16 & 23 & 51 & & 0.50 & 5.50 \\
\hline $17-4,78-80$ & & 28 & 6 & 5 & 15 & 12 & 22 & 46 & & & & & & & \\
\hline $17-6,77-79$ & & & & & 20 & 14 & 18 & 48 & & & & & & & \\
\hline
\end{tabular}


Table 1. (Continued).

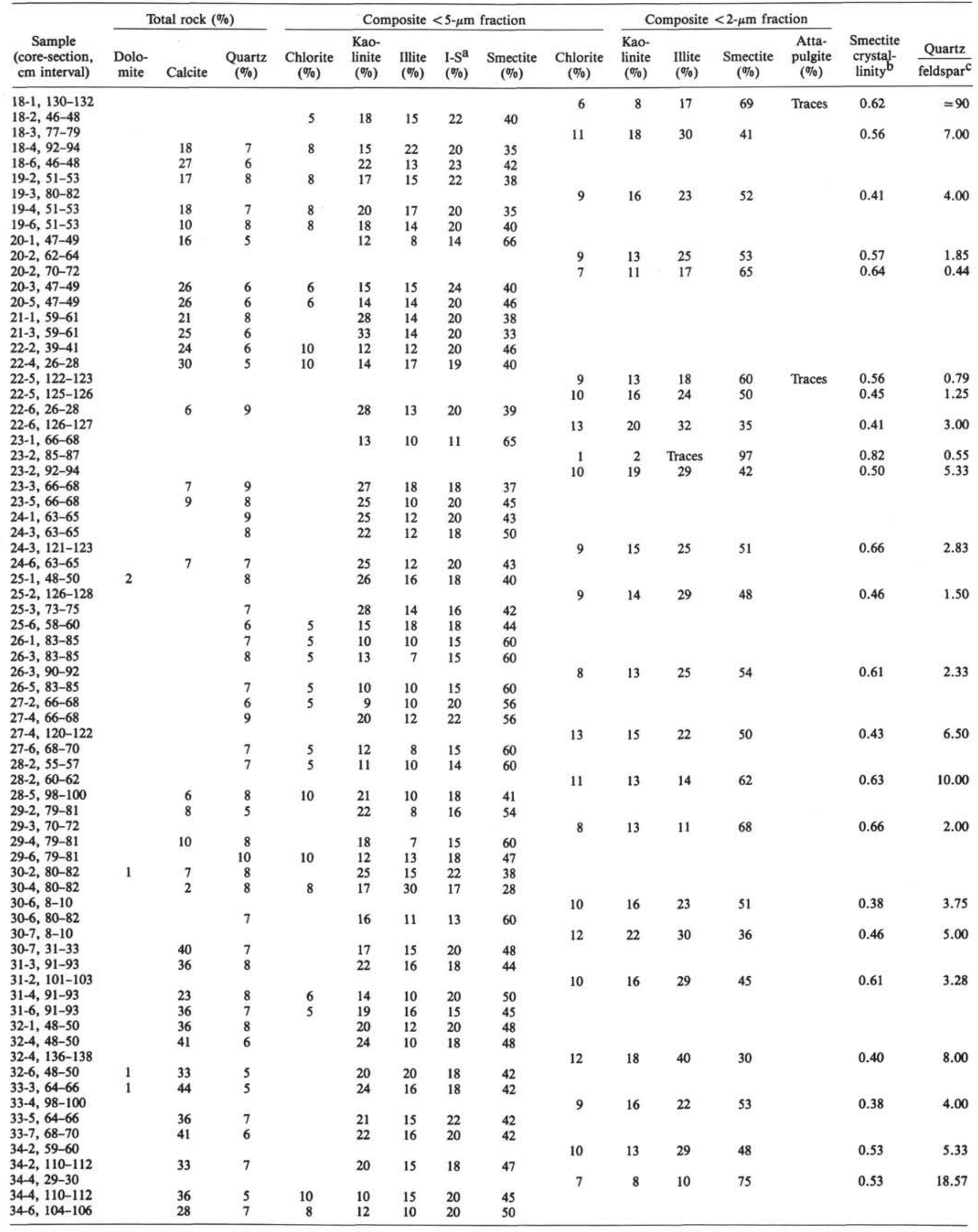


Table 1. (Continued).

\begin{tabular}{|c|c|c|c|c|c|c|c|c|c|c|c|c|c|c|c|}
\hline \multirow[b]{2}{*}{$\begin{array}{c}\text { Sample } \\
\text { (core-section, } \\
\text { cm interval) }\end{array}$} & \multicolumn{3}{|c|}{ Total rock $(\%)$} & \multicolumn{6}{|c|}{ Composite $<5-\mu \mathrm{m}$ fraction } & \multicolumn{4}{|c|}{ Composite $<2-\mu \mathrm{m}$ fraction } & \multirow[b]{2}{*}{$\begin{array}{l}\text { Smectite } \\
\text { crystal- } \\
\text { linity }\end{array}$} & \multirow[b]{2}{*}{$\frac{\text { Quartz }}{\text { feldspar }^{c}}$} \\
\hline & $\begin{array}{l}\text { Dolo- } \\
\text { mite }\end{array}$ & Calcite & $\begin{array}{c}\text { Quartz } \\
(\%)\end{array}$ & $\begin{array}{c}\text { Chlorite } \\
(\%)\end{array}$ & $\begin{array}{l}\text { Kao- } \\
\text { linite } \\
(\%)\end{array}$ & $\begin{array}{l}\text { Illite } \\
(\%)\end{array}$ & $\begin{array}{l}\text { I-S } \\
(\%)\end{array}$ & $\begin{array}{c}\text { Smectite } \\
(\%)\end{array}$ & $\begin{array}{c}\text { Chlorite } \\
(\%)\end{array}$ & $\begin{array}{l}\text { Kao- } \\
\text { linite } \\
(\%)\end{array}$ & $\begin{array}{l}\text { Illite } \\
(\%)\end{array}$ & $\begin{array}{c}\text { Smectite } \\
(\%)\end{array}$ & $\begin{array}{l}\text { Atta- } \\
\text { pulgite } \\
(\%)\end{array}$ & & \\
\hline $35-2,44-40$ & & 27 & 6 & & 20 & 15 & 20 & 45 & & & & & & & \\
\hline $35-4,44-46$ & & 8 & 6 & 3 & 5 & 2 & 10 & 80 & & & & & & & \\
\hline $35-6,24-26$ & & & & & & & & & 19 & 21 & 38 & 22 & & 0.21 & 9.50 \\
\hline $35-6,44-46$ & & 30 & 7 & 8 & 17 & 20 & 20 & 35 & & & & & & & \\
\hline $36-1,63-65$ & & 9 & 10 & & 30 & 15 & 20 & 35 & & & & & & & \\
\hline $36-2,80-82$ & & 12 & 10 & & 27 & 13 & 20 & 40 & & & & & & & \\
\hline $37-3,38-40$ & & 14 & 7 & & 20 & 15 & 15 & 50 & & & & & & & \\
\hline $37-5,43-45$ & & 4 & 10 & & 25 & 10 & 20 & 45 & & & & & & & \\
\hline $37-6,94-96$ & & & & & & & & & 13 & 24 & 32 & 31 & & 0 & 5.00 \\
\hline $38-2,76-78$ & & & & & & & & & 11 & 21 & 28 & 40 & & 0.40 & 6.50 \\
\hline $38-3,78-80$ & & 2 & 8 & & 20 & 12 & 20 & 48 & & & & & & & \\
\hline $38-6,102-104$ & & & 7 & & 15 & 5 & 12 & 68 & & & & & & & \\
\hline $39-1,91-94$ & & 2 & 8 & 5 & 9 & 8 & 18 & 60 & & & & & & & \\
\hline $39-5,50-52$ & & & 7 & & 18 & 10 & 18 & 54 & & & & & & & \\
\hline $39-5,80-82$ & & & & & & & & & 9 & 22 & 29 & 40 & & 0.27 & 4.00 \\
\hline $40-2,69-71$ & & & 9 & 8 & 16 & 6 & 18 & 52 & & & & & & & \\
\hline $40-2,126-127$ & & & & & & & & & 9 & 13 & 19 & 59 & & 0.46 & 1.66 \\
\hline $40-4,24-26$ & & & 8 & 5 & 12 & 7 & 20 & 56 & & & & & & & \\
\hline $40-6,77-79$ & & & 8 & 8 & 12 & 10 & 20 & 50 & & & & & & & \\
\hline $41-4,18-20$ & & 4 & 9 & & 25 & 7 & 20 & 48 & & & & & & & \\
\hline $41-5,20-22$ & & & 7 & & 21 & 6 & 20 & 53 & & & & & & & \\
\hline $42-4,75-77$ & & 14 & 4 & & 10 & 5 & 10 & 75 & & & & & & & \\
\hline $42-1,115-116$ & & & & & & & & & 5 & 11 & 11 & 73 & & 0.57 & 3.00 \\
\hline $42-6,120-122$ & & & 5 & & 21 & 6 & 16 & 57 & & & & & & & \\
\hline $42-7,50-52$ & & & 6 & & 20 & 10 & 14 & 56 & & & & & & & \\
\hline $43-2,94-96$ & & & & & & & & & 16 & 18 & 20 & 46 & & 0.35 & 10.00 \\
\hline $43-3,62-64$ & & & 6 & & 19 & 8 & 18 & 65 & & & & & & & \\
\hline $43-3,87-89$ & & & & & & & & & 7 & 11 & 8 & 74 & Traces & 0.68 & 1.75 \\
\hline $43-4,67-69$ & & & 7 & & 28 & 4 & 18 & 50 & & & & & & & \\
\hline $43-6,46-48$ & & & 5 & 5 & 10 & 5 & 14 & 66 & & & & & & & \\
\hline $44-3,37-39$ & & & 7 & & 17 & 5 & 10 & 68 & & & & & & & \\
\hline $44-4,90-92$ & & & 1 & & & & 5 & 95 & & & & & & & \\
\hline $45-1,136-138$ & & & & & & & & & 6 & 10 & 12 & 72 & & 0.72 & 3.00 \\
\hline $45-3,107-109$ & & & 4 & & 5 & 3 & 6 & 86 & & & & & & & \\
\hline $45-6,65-67$ & & & 7 & & 15 & 5 & 8 & 72 & & & & & & & \\
\hline $47-2,51-53$ & & & 6 & & 10 & 5 & 10 & 75 & & & & & & & \\
\hline $47-2,72-74$ & & & & & & & & & 5 & 9 & 12 & 74 & & 0.77 & 1.20 \\
\hline $48-1,35-37$ & & & 6 & & 8 & 2 & 8 & 82 & & & & & & & \\
\hline $48-4,35-37$ & & & 7 & & 8 & 4 & 6 & 82 & & & & & & & \\
\hline $48-6,35-37$ & & & 6 & & 15 & 5 & 10 & 70 & & & & & & & \\
\hline $49-3,75-77$ & & & & & & & & & 2 & 5 & 6 & 87 & & 0.81 & 2.25 \\
\hline $49-4,56-58$ & & & 6 & & 15 & 7 & 8 & 70 & & & & & & & \\
\hline $49-5,103-105$ & & & 6 & & 13 & 5 & 4 & 78 & & & & & & & \\
\hline $50-1,43-45$ & & & 6 & & 10 & 5 & 12 & 73 & & & & & & & \\
\hline $50-3,45-47$ & & & 7 & & 34 & 6 & 12 & 48 & & & & & & & \\
\hline $50-3,48-50$ & & & & & & & & & Traces & 30 & 15 & 55 & & 0.66 & 4.00 \\
\hline $50-4,41-43$ & & & 6 & & 25 & 5 & 12 & 58 & & & & & & & \\
\hline
\end{tabular}

Note: Blank space indicates no data.

a $\mathrm{I}-\mathrm{S}=$ illite-smectite $\times 100$.

b Smectite crystallinity = Biscaye index.

c Quartz/feldspar $=$ height peak ratio. 
Table 2. Leg 78A Site 542 mineralogical data obtained by X-ray diffraction analysis.

\begin{tabular}{|c|c|c|c|c|c|c|c|c|c|c|c|c|c|}
\hline \multirow[b]{2}{*}{$\begin{array}{c}\text { Sample } \\
\text { (core-section, } \\
\text { interval in cm) }\end{array}$} & \multicolumn{2}{|c|}{ Total rock $(\%)$} & \multicolumn{5}{|c|}{ Composite $<5-\mu \mathrm{m}$ fraction } & \multicolumn{4}{|c|}{ Composite $<2-\mu \mathrm{m}$ fraction } & \multirow[b]{2}{*}{$\begin{array}{l}\text { Smectite } \\
\text { crystal- } \\
\text { linity }\end{array}$} & \multirow[b]{2}{*}{$\frac{\text { Quartz }}{\text { feldsparc }}$} \\
\hline & Calcite & Quartz & $\begin{array}{l}\text { Kao- } \\
\text { linite } \\
(\%)\end{array}$ & $\begin{array}{l}\text { Illite } \\
(\%)\end{array}$ & $\begin{array}{l}\text { I-Sa } \\
(\%)\end{array}$ & $\begin{array}{c}\text { Smectite } \\
(\%)\end{array}$ & $\begin{array}{c}\text { Chlorite } \\
(\%)\end{array}$ & $\begin{array}{l}\text { Kao- } \\
\text { linite } \\
(\%)\end{array}$ & $\begin{array}{l}\text { Illite } \\
(\%)\end{array}$ & $\begin{array}{c}\text { Smectite } \\
(\%)\end{array}$ & $\begin{array}{l}\text { Atta- } \\
\text { pulgite } \\
(\%)\end{array}$ & & \\
\hline \multicolumn{14}{|l|}{ Hole 542} \\
\hline $\mathrm{H} 2-4,60-62$ & 36 & 7 & 30 & 12 & 20 & 38 & 13 & 23 & 30 & 34 & & 0.43 & 7.00 \\
\hline H3-1, 35-37 & 19 & 8 & 25 & 22 & 16 & 37 & 11 & 19 & 32 & 38 & Traces & 0.58 & 7.33 \\
\hline $2-4$ & 25 & 7 & 48 & 14 & 18 & 20 & 18 & 22 & 30 & 30 & & 0.21 & 0.50 \\
\hline $3-2,18-20$ & 21 & 7 & 30 & 10 & 20 & 40 & 15 & 19 & 39 & 27 & & 0.33 & 5.50 \\
\hline $4-1,36-37$ & 3 & 4 & & & & & & & & 99 & & 0.76 & 1.66 \\
\hline $4-1,48-49$ & 12 & 7 & & & & & 13 & 15 & 33 & 39 & & 0.35 & 5.25 \\
\hline $4-2,93-94$ & 7 & 5 & & & & & & & & & & & \\
\hline $4-2,112-113$ & 12 & 8 & & & & & 12 & 22 & 33 & 33 & & 0.38 & 5.50 \\
\hline \multicolumn{14}{|l|}{ Hole $542 \mathrm{~A}$} \\
\hline H1-5, 87-89 & 32 & 5 & 34 & 16 & 21 & 29 & 11 & 18 & 27 & 44 & & 0.46 & 2.22 \\
\hline $\mathrm{H} 2-5,60-62$ & 7 & 6 & 26 & 12 & 18 & 44 & 10 & 15 & 31 & 44 & Traces & 0.23 & 0.78 \\
\hline $1-4,61-63$ & 30 & 6 & 28 & 14 & 18 & 40 & 11 & 20 & 29 & 40 & & 0.50 & 5.50 \\
\hline $2-1,60-62$ & & 7 & 32 & 12 & 18 & 38 & 9 & 17 & 33 & 41 & Traces & 0.30 & 6.50 \\
\hline $3-1,106-108$ & & & & & & & 5 & 7 & 16 & 72 & Traces & 0.60 & 1.25 \\
\hline $3-2,106-108$ & & 6 & 15 & 5 & 15 & 65 & & & & & & & \\
\hline $3-3,101-103$ & & 8 & 19 & 9 & 15 & 57 & & & & & & & \\
\hline $4-2,78-80$ & 2 & 7 & 33 & 9 & 18 & 40 & 13 & 22 & 22 & 43 & & 0.41 & 10.00 \\
\hline $4-2,119-121$ & 14 & 8 & 27 & 16 & 17 & 40 & & & & & & & \\
\hline $4-3,126-128$ & & 7 & 32 & 9 & 17 & 42 & 14 & 16 & 17 & 53 & & 0.53 & 11.60 \\
\hline $5-4,60-62$ & 2 & 6 & 25 & 9 & 16 & 50 & 10 & 18 & 21 & 51 & & 0.44 & 3.00 \\
\hline $6-1,127-129$ & 4 & 6 & 20 & 5 & 15 & 60 & & & & & & & \\
\hline $6-2,92-94$ & 9 & 5 & & & & & 7 & 11 & 11 & 71 & & 0.61 & 1.50 \\
\hline $7-1,98-100$ & & 7 & 32 & 6 & 15 & 47 & & & & & & & \\
\hline $7-2,6-8$ & & 7 & 30 & 10 & 16 & 44 & 10 & 25 & 15 & 50 & & 0.64 & 4.50 \\
\hline $8-3,92-94$ & & 6 & 28 & 6 & 16 & 50 & & & & & & & \\
\hline $8-4,40-42$ & & 5 & 18 & 6 & 14 & 62 & 7 & 10 & 10 & 73 & & 0.58 & 3.50 \\
\hline
\end{tabular}

Note: Blank spaces indicate no data.

a $\mathrm{I}-\mathrm{S}=$ illite-smectite $\times 100$.

b Smectite crystallinity = Biscaye index.

c Quartz/feldspar = height peak ratio. 


\section{LATOUCHE, N. MAILI FT}

Table 3. Leg 78A Site 543 mineralogical data obtained by X-ray diffraction analysis.

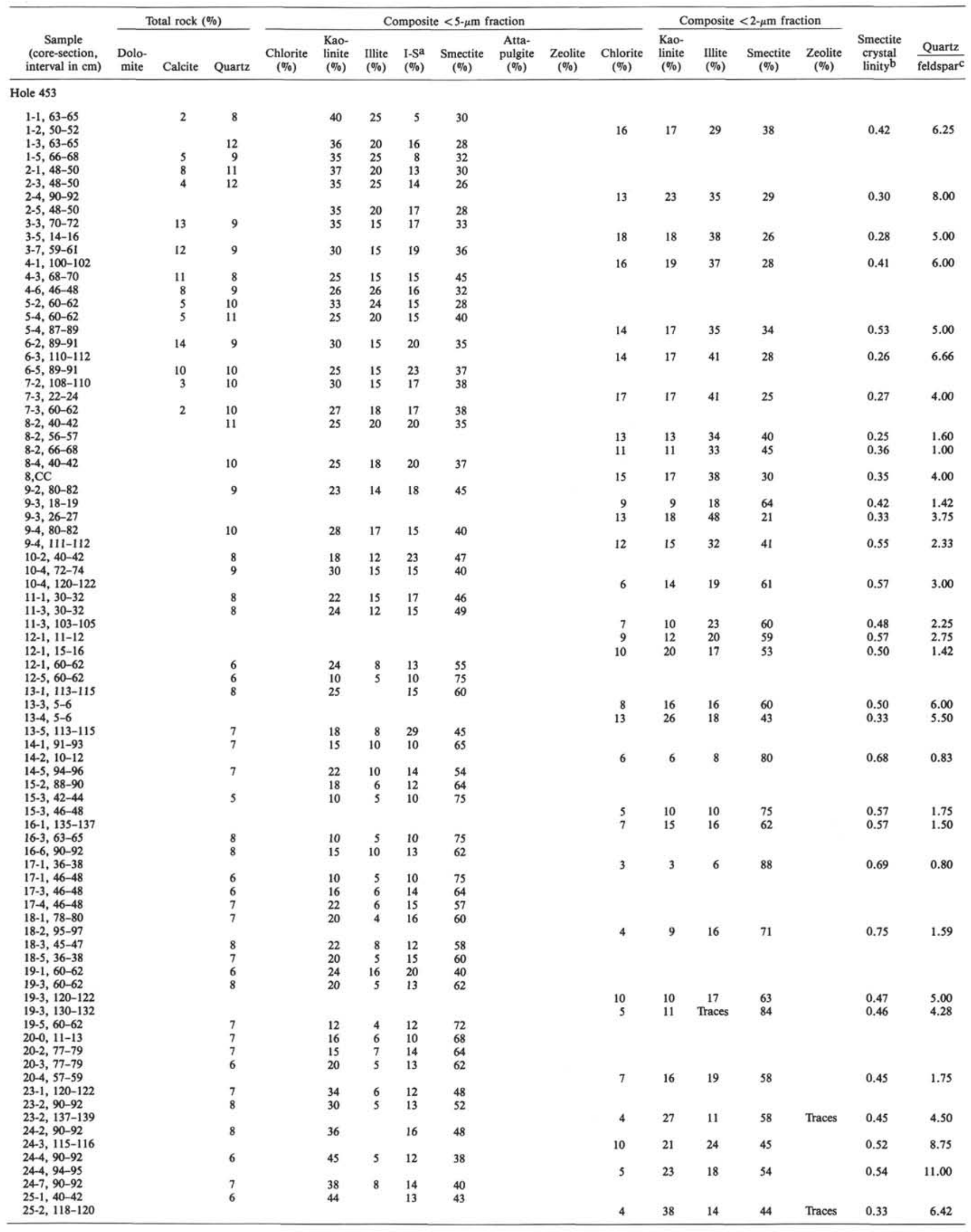


Table 3. (Continued).

\begin{tabular}{|c|c|c|c|c|c|c|c|c|c|c|c|c|c|c|c|c|c|}
\hline \multirow[b]{2}{*}{$\begin{array}{c}\text { Sample } \\
\text { (core-section, } \\
\text { interval in cm) }\end{array}$} & \multicolumn{3}{|c|}{ Total rock $(\%)$} & \multicolumn{8}{|c|}{ Composite $<5-\mu \mathrm{m}$ fraction } & \multicolumn{4}{|c|}{ Composite $<2-\mu \mathrm{m}$ fraction } & \multirow[b]{2}{*}{$\begin{array}{l}\text { Smectite } \\
\text { crystal } \\
\text { linity }^{\mathrm{b}}\end{array}$} & \multirow[b]{2}{*}{$\frac{\text { Quartz }}{\text { feldsparc }^{c}}$} \\
\hline & $\begin{array}{l}\text { Dolo- } \\
\text { mite }\end{array}$ & Calcite & Quartz & $\begin{array}{c}\text { Chlorite } \\
(\%)\end{array}$ & $\begin{array}{l}\text { Kao- } \\
\text { linite } \\
(\%)\end{array}$ & $\begin{array}{l}\text { Illite } \\
(\%)\end{array}$ & $\begin{array}{l}\text { I-Sa } \\
(\%)\end{array}$ & $\begin{array}{c}\text { Smectite } \\
(\%)\end{array}$ & $\begin{array}{c}\text { Atta- } \\
\text { pulgite } \\
(\%)\end{array}$ & $\begin{array}{c}\text { Zeolite } \\
(\%)\end{array}$ & $\begin{array}{c}\text { Chlorite } \\
(\%)\end{array}$ & $\begin{array}{l}\text { Kao- } \\
\text { linite } \\
(\%)\end{array}$ & $\begin{array}{l}\text { Illite } \\
(\%)\end{array}$ & $\begin{array}{c}\text { Smectite } \\
(\%)\end{array}$ & $\begin{array}{c}\text { Zeolite } \\
(\%)\end{array}$ & & \\
\hline \multicolumn{18}{|l|}{ Hole 453 (Cont.) } \\
\hline $25-2,122-123$ & & & & & & & & & & & 3 & 34 & 13 & 50 & & 0.45 & 11.00 \\
\hline $25-3,11-13$ & & & 8 & & 54 & & 12 & 34 & & & & & & & & & \\
\hline $26-1,27-29$ & & & 8 & & 40 & 10 & 12 & 38 & & & & & & & & & \\
\hline $26-3,27-29$ & & & 6 & & 50 & & 12 & 38 & & & & & & & & & \\
\hline $26-4,110-112$ & & & & & & & & & & & 2 & 22 & 9 & 67 & Traces & 0.62 & 7.10 \\
\hline $26-5,27-29$ & & & 6 & & 35 & & 13 & 52 & & & & & & & & & \\
\hline $27-1,83-85$ & & & 8 & & 43 & 7 & 10 & 40 & & & & & & & & & \\
\hline $27-3,24-26$ & & & 6 & & 40 & & 10 & 50 & & & & & & & & & \\
\hline $27-4,83-85$ & & & & & & & & & & & Traces & 34 & 9 & 57 & & 0.62 & 7.00 \\
\hline $27-5,33-35$ & & & 7 & & 40 & 10 & 10 & 40 & & & & & & & & & \\
\hline $28-1,66-68$ & & & 6 & & 35 & & 7 & 58 & & & & & & & & & \\
\hline $28-2,66-68$ & & & 5 & & 35 & 5 & 12 & 48 & & & & & & & & & \\
\hline $28-3,81-83$ & & & & & & & & & & & Traces & 32 & 7 & 61 & Traces & 0.61 & 5.00 \\
\hline $28-4,66-68$ & & & 5 & & 40 & & 10 & 50 & & & & & & & & & \\
\hline $29-1,63-65$ & & & 5 & & 40 & 10 & 12 & 38 & & & & & & & & & \\
\hline $29-1,12-14$ & & & 4 & & 45 & & 10 & 45 & & & & & & & & & \\
\hline $29-3,31-33$ & & & & & & & & & & & 3 & 27 & 6 & 64 & Traces & 0.67 & 3.33 \\
\hline $29-3,79-81$ & & & 3 & & 35 & 5 & 10 & 50 & & & & & & & & & \\
\hline $29-3,87-89$ & & & & & & & & & & & 4 & 23 & 8 & 65 & Traces & 0.68 & 6.66 \\
\hline $29-6,133-135$ & & & 2 & & 30 & & 12 & 58 & & & & & & & & & \\
\hline $30-2,9-11$ & & & 2 & & 35 & & 10 & 55 & & & & & & & & & \\
\hline $30-4,9-11$ & & & 5 & & 30 & 15 & 15 & 40 & & & & & & & & & \\
\hline $30-4,93-94$ & & & & & & & & & & & Traces & 21 & 8 & 71 & Traces & 0.54 & 2.08 \\
\hline $30-6,82-84$ & & & 3 & & 35 & & 10 & 55 & & & & & & & & & \\
\hline $31-1,28-30$ & & & 4 & & 40 & & 10 & 50 & & & & & & & & & \\
\hline $32-2,76-78$ & & & 4 & & 40 & & 12 & 48 & & & & & & & & & \\
\hline $32-3,78-80$ & & & 4 & & 17 & & 18 & 37 & 28 & & & & & & & & \\
\hline $32-4,69-73$ & & & 4 & & 15 & & 10 & 35 & 40 & & & & & & & & \\
\hline $33-1,25-27$ & & & 4 & & 20 & & 15 & 45 & 20 & & & & & & & & \\
\hline $33-3,53-55$ & & & 3 & & 30 & 5 & 17 & 48 & & & & & & & & & \\
\hline $34-1,6-8$ & & & 4 & & 17 & 14 & 10 & 45 & & $\mathrm{x}$ & & & & & & & \\
\hline $34-2,63-65$ & & & 4 & & 20 & 8 & 10 & 50 & & $\mathrm{X}$ & & & & & & & \\
\hline \multicolumn{18}{|l|}{ Hole 453A } \\
\hline $1-2,136-137$ & & & & & & & & & & & 11 & 22 & 29 & 38 & & 0.24 & 8.00 \\
\hline $1-2,137-138$ & & & & & & & & & & & 14 & 21 & 31 & 34 & Traces & 0.43 & 7.66 \\
\hline $1-4,32-33$ & & & & & & & & & & & 12 & 20 & 31 & 37 & & 0.36 & 3.60 \\
\hline $2-1,97-99$ & & & 5 & & 18 & 10 & 13 & 43 & & $\mathrm{x}$ & & & & & & & \\
\hline $2-2,64-66$ & & & 5 & & 22 & & 18 & 50 & & $\mathrm{x}$ & & & & & & & \\
\hline $3-1,86-88$ & & & 8 & & 15 & 5 & 10 & 55 & & $\mathrm{X}$ & & & & & & & \\
\hline $3-2,111-113$ & & & 10 & & 15 & 5 & 10 & 55 & & $\mathrm{X}$ & & & & & & & \\
\hline $4-1,56-58$ & & & 9 & & 15 & & 12 & 58 & & $\mathrm{x}$ & & & & & & & \\
\hline $4-2,58-60$ & & & 9 & & 15 & 5 & 10 & 55 & & $\mathrm{x}$ & & & & & & & \\
\hline $4-3,75-77$ & & & 8 & & 24 & 6 & 10 & 55 & & $\mathrm{x}$ & & & & & & & \\
\hline $5-1,29-31$ & & & 8 & & 20 & 5 & 10 & 65 & & & & & & & & & \\
\hline $5-3,39-41$ & & & 11 & & 20 & 15 & 17 & 48 & & & & & & & & & \\
\hline $6-1,35-37$ & & & 12 & & 30 & 10 & 14 & 46 & & & & & & & & & \\
\hline $7-2,7-9$ & & & & & & & & & & & 7 & 16 & 10 & 67 & & 0.55 & 6.00 \\
\hline $7-2,43-45$ & & & 10 & 5 & 20 & 15 & 18 & 42 & & & & & & & & & \\
\hline $7-3,9-11$ & & 47 & 5 & 5 & 15 & 15 & 20 & 45 & & & & & & & & & \\
\hline $7-3,12-13$ & & 10 & 7 & 5 & 20 & 10 & 20 & 45 & & & & & & & & & \\
\hline $8-1,85-87$ & 1 & & 9 & 5 & 15 & 30 & 20 & 30 & & & & & & & & & \\
\hline $9-1,20-22$ & 3 & 11 & 8 & 5 & 13 & 40 & 18 & 24 & & & & & & & & & \\
\hline $10-1,18-19$ & & 44 & 4 & 5 & 5 & 45 & 20 & 25 & & & & & & & & & \\
\hline
\end{tabular}

Note: Blank spaces indicate no data. $\mathbf{X}=$ present.

a $\mathrm{I}-\mathrm{S}=$ illite-smectite $\times 100$.

b Smectite crystallinity $=$ Biscaye index.

c Quartz/feldspar = height peak ratio. 


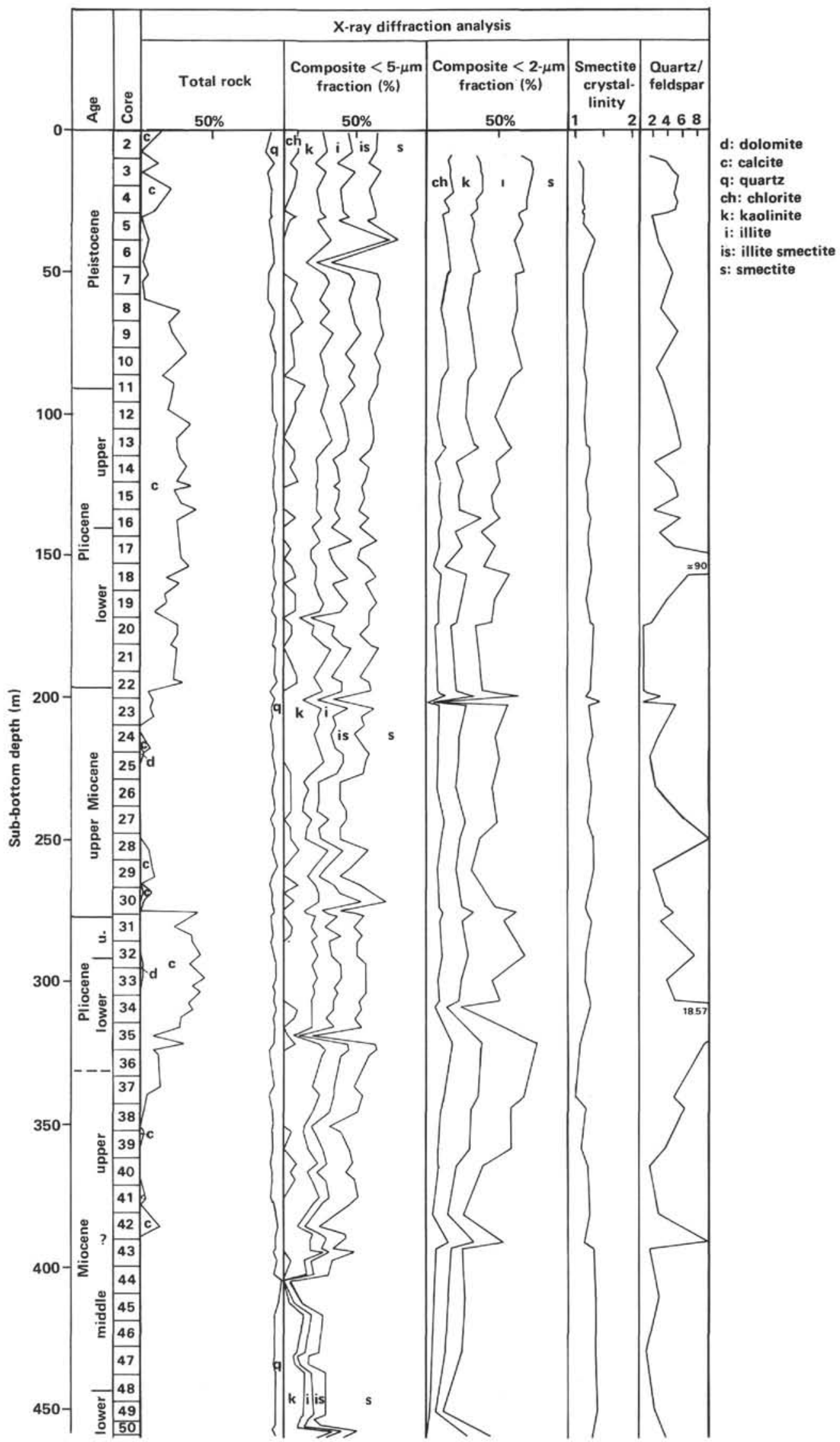

Figure 1. Variations of mineralogical data at Site 541 plotted versus age, depth sub-bottom, and core. 


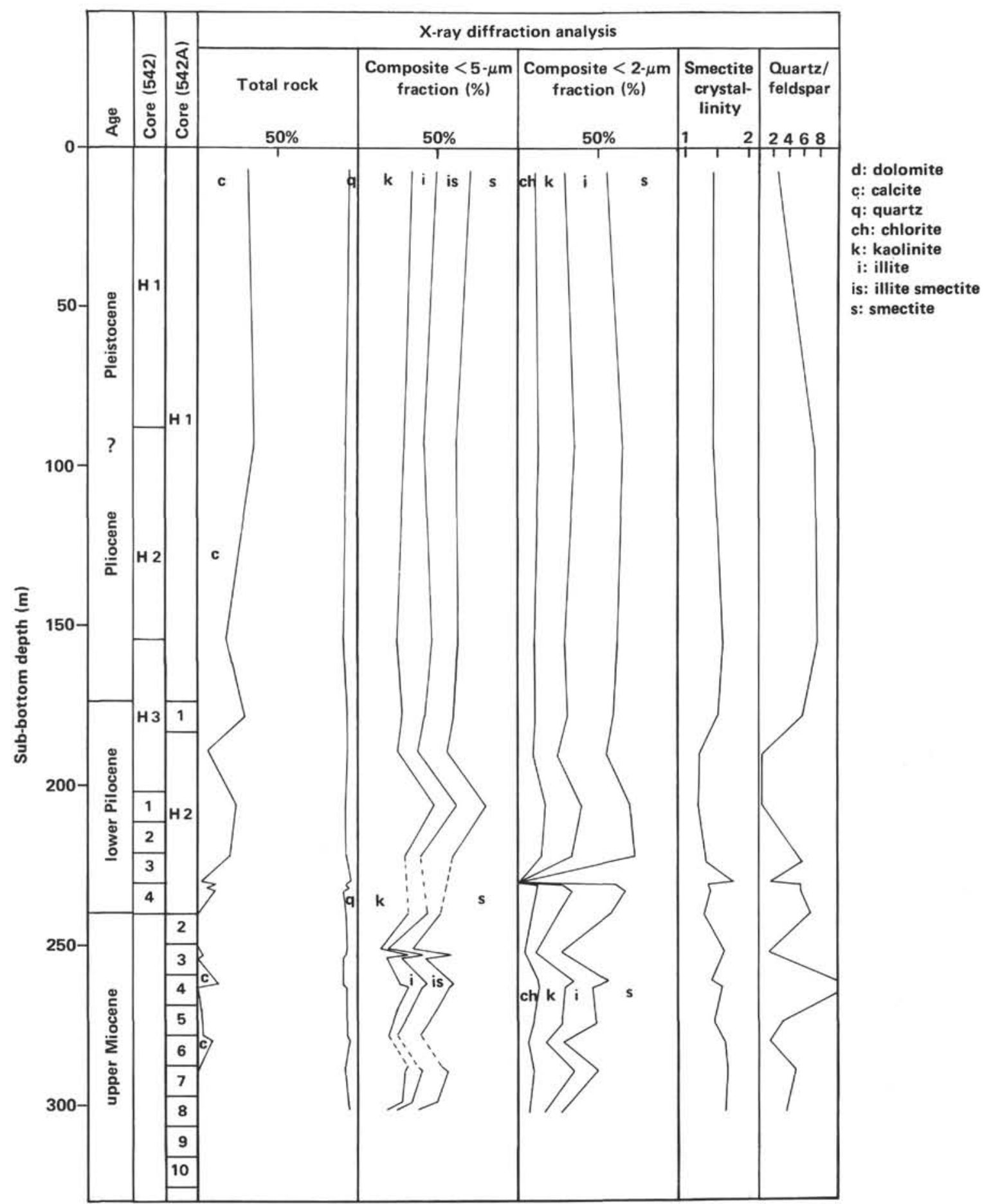

Figure 2. Variations of mineralogical data at Site 542, plotted versus age, depth sub-bottom, and core. 


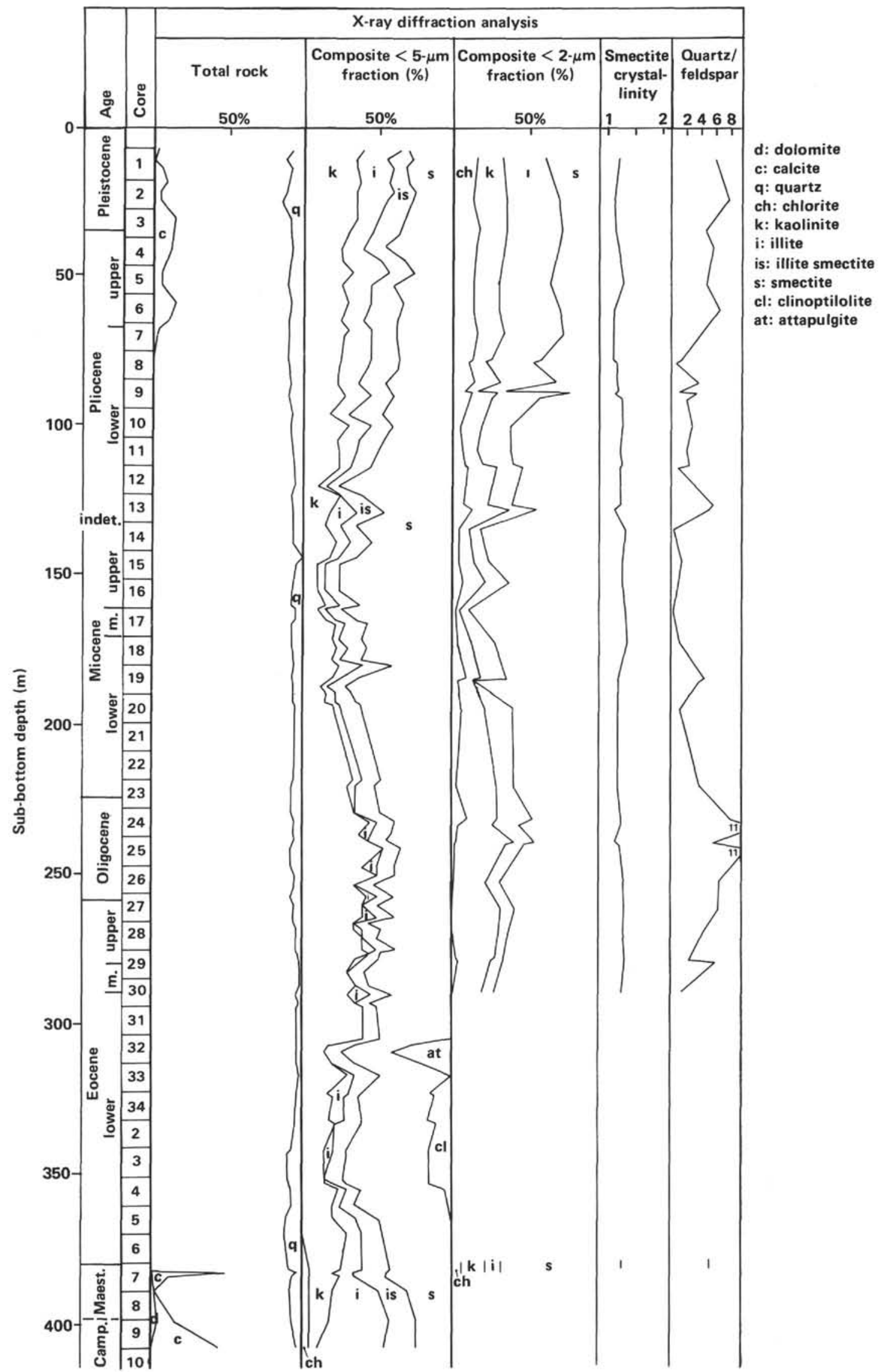

Figure 3. Variations of mineralogical data at Site 543, plotted versus age, depth sub-bottom, and core. 